Володимир Колесник, кандидат технічних наук, старший науковий співробітник ORCID ID 0000-0002-6323-7748

Руслан Серветник, кандидат педагогічних наук, старший науковий співробітник,

ORCID ID 0000-0001-5624-4889

Національний університет оборони України імені Івана Черняховського

\title{
ПРОБЛЕМНІ ПИТАННЯ МЕХАНІЗМУ ПІДГОТОВКИ ДОКТОРІВ ФІЛОСОФІЇ ПОЗА АД'ЮНКТУРОЮ
}

У статті окреслено проблемні питання механізму здобуття вищої освіти ступеня доктора філософії поза ад'юнктурою та можливі иляхи вирішення протиріч чинної нормативно-правової бази щэодо організації підготовки здобувачів вищої освіти у вищих військових навчальних закладах (наукових установах).

Ключові слова: вищий військовий навчальний заклад; освітньо-наукова програма; підготовка здобувачів вищої освіти ступеня доктора філософії; нормативно-правові документи.

Постановка проблеми. Упродовж останніх десяти років під час дискусій щодо реформи вищої освіти в Україні предметом було обговорення питання вдосконалення освітнього аспекту підготовки здобувачів вищої освіти переважно в межах приєднання до Болонського процесу (Болонської декларації й Берлінського комюніке), спроби інтеграції українського досвіду та його розвитку в нових умовах. Також це зумовлено:

- переходом світової спільноти до інформаційного суспільства, оволодіння навичками пошуку інформації, здатності до самонавчання протягом життя, де ці новоутворення стають визначальною сферою професійної діяльності людини [1];

- особливою актуалізацією глобалізації усіх сфер життєдіяльності особистості та суспільства в умовах загальноцивілізаційних тенденцій сучасного світу, що вимагає від вищої школи надати молодій людині елементарні можливості інтегруватися в різні соціуми, самовизначатися в житті, активно діяти, бути конкурентоспроможною [2].

Аналіз останніх досліджень i публікацій. Проблема модернізації механізму підготовки доктора філософії поза ад'юнктурою набула значної актуальності, про що свідчать праці 3 цієї тематики: у площині методологічного осмислення проблеми - А. Алексюка, В. Андрущенка, I. Зязюна, В. Кременя, В. Майбороди, О. Савченко; аналізу докторської освіти в зарубіжних країнах - В. Лугового, В. Лутай, Л. Лобанова, О. Поживілова, Ж. Таланова; 3 нормативно-правового регулювання підготовки й атестації наукових і науково-педагогічних кадрів в Україні - 
Л. Лисенко [3], Б. Пережняка [4], О. Поповича [5], В. Чмиги [6]; формування цілісної, творчої, соціально активної, духовно багатої особистості О. Романовського, М. Лазарєва, О. Коваленка, І. Прокопенка, Ю. Нагірного, В. Ягупова.

Зокрема вітчизняними науковцями було здійснено аналіз результатів атестації наукових кадрів вищої кваліфікації в Україні, розглянуто поняття атестації наукових кадрів із правової точки зору, визначено інституційноправові засади підготовки й атестації наукових і науково-педагогічних кадрів в Україні у процесі становлення та розвитку. Як зазначає I. Зязюн, «..головною метою вищої освіти має бути становлення цілісної й цілеспрямованої особистості, готової до вільного гуманістичного орієнтованого вибору та індивідуального інтелектуального зусилля, що володіє багатофункціональними компетентностями» [7, с. 13].

Мета статті полягає в розроблені методичних i практичних рекомендацій щодо підготовки військових кадрів вищої кваліфікації поза ад'юнктурою, висвітлення проблемних питань, із якими можуть зіштовхуватися посадові особи, які займаються організацією підготовки наукових та науково-педагогічних кадрів у вищих військових навчальних закладах (науково-дослідних установах).

Виклад основного матеріалу. Сутність реформи військової освіти полягає в тому, щоб одночасно 3 реорганізацією військової компоненти створити відповідну їй систему підготовки офіцерських кадрів вищої кваліфікації, що відповідатиме новій структурі й завданням збройних сил та буде спроможна забезпечувати професійне виконання завдань за призначенням. Сучасні тенденції розвитку Збройних Сил України висувають нові вимоги до підготовки здобувачів вищої освіти ступеня доктора філософії поза ад'юнктурою у вищих військових навчальних закладах (далі - ВВН3), а це означає, що пріоритетом $є$ не просте накопичення знань і предметних умінь та навичок, а підготовка висококваліфікованого військового фахівця певного рівня і профілю, конкурентоздатного, компетентного, який вільно володіє професією військового й орієнтується в суміжних галузях діяльності, готового до постійного професійного росту, соціальної та професійної мобільності.

Необхідно зазначити, що відповідно до прийнятих законодавчих актів у сфері вищої освіти встановлюються норми, які відповідають традиціям розвинених європейських держав i розглядають підготовку докторів філософії поза ад'юнктурою як фахівців освітньо-наукового рівня вищої освіти, що є новим. Крім того ВВНЗ набуває більшої самостійності та стає генератором ідей, моделей військово-професійної діяльності, ініціатором і провідником їх підготовки. У нормативно-правових документах [8; 9] зазначено основні нововведення, а саме:

- поза ад’юнктурою здійснюється підготовка здобувачів вищої освіти ступеня доктора філософії (для осіб, які професійно проводять наукову, 
науково-технічну або науково-педагогічну діяльність за основним місцем роботи у ВВНЗ (НУ);

- здобувачі вищої освіти ступеня доктора філософії поза ад’юнктурою прикріплюються строком до п'яти років до ВВНЗ (НУ), що має ліцензію на провадження освітньої діяльності на третьому (освітньо-науковому) рівні вищої освіти за відповідною спеціальністю;

- здобуття вищої освіти ступеня доктора філософії поза ад'юнктурою передбачає повне й успішне виконання освітньо-наукової програми та навчального плану ад'юнктури зазначеного ВВН3 (НУ) згідно із затвердженими в установленому порядку індивідуальним навчальним планом та індивідуальним планом наукової роботи прикріпленої особи, публічний захист дисертації у спеціалізованій вченій раді;

- навчання для реалізації свого права на здобуття вищої освіти ступеня доктора філософії поза ад’юнктурою, а також наукове керівництво здобувачів здійснюється за кошти відповідного ВВНЗ (НУ). Але в жодному 3 них не розкрито повною мірою механізм їх підготовки, а віддано на вирішення вченої ради, яка має визначити правила та процедури прикріплення до ВВНЗ (НУ) [9].

Таким чином, на сьогодні склалася ситуація, коли жоден чинний нормативно-правовий документ не визначає в завершеному вигляді механізм здобуття вищої освіти ступеня доктора філософії поза ад’юнктурою. Тому виникає нагальна необхідність обговорення низки основних проблемних питань, які потрібно (регламентувати) закріпити у відповідних правилах i процедурах для того, щоб уникнути подвійного тлумачення, а саме:

- порядок фінансування підготовки здобувачів вищої освіти ступеня доктора філософії поза ад’юнктурою;

- порядок відбору кандидатів на підготовку докторів філософії поза ад’юнктурою;

- як поєднати службову (трудову) діяльність здобувача й виконання освітньо-наукової програми та навчального плану ад’юнктури.

Нормативними документами визначено, що «...підготовка здобувачів вищої освіти ступеня доктора філософії за державним замовленням здійснюється виключно в аспірантурі (ад’юнктурі)...» [9]. Отже, можна стверджувати, що у ВВН3 (НУ) вона здійснюватиметься тільки за рахунок коштів юридичних чи фізичних осіб (на умовах контракту). Зокрема це можуть бути кошти грантів, що отримав ВВН3 (НУ) на проведення наукових досліджень, за якими передбачається підготовка здобувачів вищої освіти ступеня доктора філософії поза ад'юнктурою.

На перший погляд, про порядок відбору кандидатів на підготовку докторів філософії поза ад'юнктурою дають відповіді вище згадувані нормативні документи, водночас ними він не регламентований. Хтось може сказати, якщо не визначено нормативними документами порядок відбору кандидатів на підготовку здобувачів вищої освіти ступеня доктора філософії 
поза ад'юнктурою, то його й не має бути, а досить лише тільки бажання здобувача. Безумовно, воно є необхідною умовою, але цього не достатньо.

На нашу думку, відбір має здійснюватись обов'язково, адже здобуття вищої освіти ступеня доктора філософії поза ад'юнктурою передбачає повне й успішне виконання освітньо-наукової програми, навчального плану згідно iз затвердженими в установленому порядку індивідуальним навчальним планом та індивідуальним планом наукової роботи прикріпленої особи, публічний захист дисертації у спеціалізованій вченій раді [9]. Виконання такого обсягу роботи в термін до п’яти років потребує певного рівня знань, набутих на попередніх етапах навчання, що й необхідно перевіряти в кандидатів перед прийняттям рішення про їх закріплення здобувачами.

Пропонується проводити їх відбір у формі співбесіди за тими ж дисциплінами, що й для кандидатів для вступу до ад'юнктури. Він може бути виконаний у терміни, що б дали змогу здійснювати підготовку здобувачів вищої освіти ступеня доктора філософії, які працюють поза ад’юнктурою, паралельно з підготовкою ад’юнктів, a, можливо, для деяких дисциплін і в одних групах.

Наступне проблемне питання, як поєднати службову (трудову) діяльність здобувача й виконання освітньо-наукової програми та навчального плану ад'юнктури. Адже Порядок підготовки чітко визначає, що «...Усі аспіранти (ад'юнкти) незалежно від форми навчання зобов'язані відвідувати аудиторні заняття i проходити всі форми поточного й підсумкового контролю, передбачені індивідуальним навчальним планом аспіранта (ад'юнкта) та освітньо-науковою програмою аспірантури (ад'юнктури) вищого навчального закладу (наукової установи)» [9]. Для цивільних осіб це може бути перебування у творчій відпустці або навчання за вечірньою формою. Для військовослужбовців, які бажають здобувати вищу освіту ступеня доктора філософії, на сьогодні ми бачимо лише тільки один шлях вступ до ад’юнктури.

3 цією метою «Особливостями підготовки здобувачів вищої освіти ступеня доктора філософії та доктора наук у вищих військових навчальних закладах (науково-дослідних установах) Міністерства оборони України», затверджених наказом Міністерства оборони України від 24 лютого 2017 року № 115, вік для вступників до ад’юнктури збільшено. Тепер для офіцерів, які здобули вищу освіту ступеня магістра (спеціаліста), він становить до 45 років включно, а для офіцерів, які отримали вищу освіту оперативно-стратегічного рівня - до 47 років [10]. А це, головним чином, від 15 до 22 років військової служби на посадах офіцерського складу, що дасть змогу використати свій службовий досвід при підготовці дисертаційної роботи, а в подальшому при проходженні військової служби або ж, працюючи на посадах науково-педагогічних (наукових) працівників, передати його курсантам і слухачам.

Необхідно зауважити, що при вступі до ад’юнктури за офіцерами зберігаються посадові оклади за останніми штатними посадами, які вони 
займали до зарахування на навчання [11]. I хоча на сьогодні діє обмеження оклад офіцерів, зарахованих до ад'юнктури, не може перевищувати оклад начальника кафедри, за якою він закріплений згідно з наказом, керівництвом Міністерства оборони України й Національного університету оборони України імені Івана Черняховського ведеться робота для його зняття. Це дасть змогу офіцерам із посад начальника відділу - заступника начальника окремого управління, заступника начальника управління, начальника управління Центрального апарату Міністерства оборони України (Генерального штабу Збройних Сил України), які мають унікальний досвід проходження військової служби, вступати до ад’юнктури без зменшення своїх соціальних гарантій, а в науковому дослідженні застосувати особистий досвід і зробити неоціненний внесок у розвиток теорії застосування військ (сил). Втілення в життя вищезазначених заходів дало уже перші позитивні результати. Набір в ад'юнктуру Національного університету оборони України імені Івана Черняховського у 2017 році було виконано на 100 \% (60$70 \%$ - показники попередніх років). При цьому конкурс мав місце за чотирма із шести спеціальностей.

Висновки та перспективи подальших досліджень. Значна частина проблемних питань механізму підготовки здобувачів вищої освіти ступеня доктора філософії поза ад'юнктурою спричинена вимогами чинних нормативно-правових актів. Заходи з їх вирішення передбачатимуть внесення змін, скасування або збільшення нормативно-правових актів. На жаль, у багатьох наукових галузях i структурі BВН3 (НУ) бракує висококваліфікованих фахівців із відповідними знаннями. Тому розглянуті проблемні питання потребують особливої уваги керівників, діяльність яких пов'язана з підготовкою військових кадрів вищої кваліфікації.

Перспектива подальших наукових досліджень вбачається у з'ясуванні проблемних питань у змістовному наповненні індивідуальних навчальних планів здобувачів вищої освіти ступеня доктора філософії, які мають забезпечити формування визначених компетентностей для вирішення проблем різної складності в майбутній науково-педагогічній (науковій) діяльності.

\section{ЛІТЕРАТУРА}

1. Компетентнісний підхід у сучасній освіті: світовий досвід та українські перспективи [текст] // Бібліотека з освітньої політики / під заг. ред. О. В. Овчарук. - К. : «K.I.C.», 2004. - $112 \mathrm{c.}$

2. Кремень В. Г. Нові вимоги до якісної освіти [текст] / В. Г. Кремень // Освіта України. - 2006. - № 45-46. - С. 6-7.

3. Лисенко Л. В. Нормативно-правове регулювання підготовки та атестації наукових і науково-педагогічних кадрів 3 державного управління в Україні [Електронний ресурс] / Л. Лисенко. - Режим доступу: http://www.dridu.dp.ua/vidavnictvo/2009/200902(2)/Lysenko.pdf/. - Назва з екрана.

4. Пережняк Б. А. Організація управління атестацією наукових i науковопедагогічних кадрів вищої кваліфікації в Україні / Б. А. Пережняк // Актуальні проблеми 
держави і права / голов. ред. С. В. Ківалов. - 2003. - Вип. 21. - Одеса : Юрид. л-ра, 2003. С. 159-166.

5. Попович О. С. Проблеми вдосконалення правового забезпечення підготовки та атестації наукових кадрів вищої кваліфікації в Україні / О. С. Попович, Л. С. Лобанова // Наука та наукознавство. - 2004. - № 1. - С. 44-50.

6. Чмига В. О. Аналіз результатів атестації наукових кадрів вищої кваліфікації в Україні за 15-річний період функціонування галузі науки “державне управління" [Електронний ресурс] / В. О. Чмига, Н. І. Демедишина // Аналітика і влада. - 2012. - № 6. - C. 38-45. - Режим доступу: http://nbuv.gov.ua/UJRN/avlad_2012_6_9.

7. Зязюн I. А. Філософія поступу і прогнозу освітньої системи [текст] // Педагогічна майстерність: проблеми, пошуки, перспективи: [монографія] / І. А. Зязюн. - К.; Глухів : РВВ ГДПУ, 2005. - С. 10-18.

8. Закон України “Про вищу освіту”, від 1 липня 2014 року № 1556-VII.

9. Постанова Кабінету Міністрів України від 23 березня 2016 року № 261 "Порядок підготовки здобувачів вищої освіти ступеня доктора філософії та доктора наук у вищих навчальних закладах (наукових установах)" [Електронний ресурс]. - Режим доступу: ttp://www.kmu.gov.ua/control/uk/cardnpd?docid=248945529.

10. Наказ Міністерства оборони України від 24 лютого 2017 року № 115 “Особливості підготовки здобувачів вищої освіти ступеня доктора філософії та доктора наук у вищих військових навчальних закладах (науково-дослідних установах) Міністерства оборони України".

11. Наказ Міністерства оборони України від 11 червня 2008 року № 260 "Про затвердження Інструкції про порядок виплати грошового забезпечення військовослужбовцям Збройних Сил України та деяким іншим особам”.

\section{REFERENCES}

1. Ovcharuk, O.V. (2004), "Kompetentnisnyi pidkhid u suchasnii osviti: svitovyi dosvid ta ukrainski perspektyvy" [Competency approach in modern education: world experience and Ukrainian perspectives], K.I.S., Kiev, 112 p.

2. Kremen, V.G. (2006), "Novi vymohy do yakisnoi osvity" [New requirements for qualitaty education] Education of Ukraine, № 45-46, pp. 6-7.

3. Lysenko, L.V. (2009), "Normatyvno-pravove rehuliuvannia pidhotovky ta atestatsii naukovykh i naukovo-pedahohichnykh kadriv z derzhavnoho upravlinnia v Ukraini" [Normative and legal regulation of training and attestation of scientific and scientific and pedagogical staff on public administration in Ukraine], available at: http://www.dridu.dp.ua/vidavnictvo/2009/2009-02(2)/Lysenko.pdf/.

4. Perezhnyak, B. A. (2003), "Orhanizatsiia upravlinnia atestatsiieiu naukovykh i naukovopedahohichnykh kadriv vyshchoi kvalifikatsii v Ukraini” [Organization of attestation management of scientific and scientific and pedagogical staff of higher qualification in Ukraine], Actual problems of state and law, №21, pp. 159-166.

5. Popovich, O. S., Lobanova, L.S. (2004), "Problemy vdoskonalennia pravovoho zabezpechennia pidhotovky ta atestatsii naukovykh kadriv vyshchoi kvalifikatsii v Ukraini" [Problems of legal support improvement of training and attestation of scientific staff of higher qualification in Ukraine], Nauka i naukoznavstvo, №1, pp. 44-50.

6. Chmyha, V. O., Demedishina, N. I. (2012), "Analiz rezultativ atestatsii naukovykh kadriv vyshchoi kvalifikatsii v Ukraini za 15-richnyi period funktsionuvannia haluzi nauky "derzhavne upravlinnia" [Analysis of the results of the certification of higher professional qualifications in Ukraine for the 15-year period of the functioning of the science sector "public administration"], available at: http://nbuv.gov.ua/UJRN/avlad_2012_6_9.

7. Zyazun, I.A. (2005), "Filosofiia postupu i prohnozu osvitnoi systemy. Pedahohichna maisternist: problemy, poshuky, perspektyvy" [Philosophy of progress and forecast of the 
educational system. Pedagogical Skills: Problems,Search, Perspectives], Glukhiv: RVV GDPU, Kiev, pp. 10-18.

8. Law of Ukraine "On Higher Education", dated July 1, 2014 ,n.o. 1556-VII, available at: http//www.zakon.rada.gov.ua.

9. Resolution of the Cabinet of Ministers of Ukraine "Procedure for the training of higher education Doctor of Philosophy and Doctor of Science candidates at higher educational institutions (scientific institutions) as of March 23, 2016, n.o. 261, available at: http//www.zakon.rada.gov.ua.

10. Order of the Ministry of Defense of Ukraine "Features of training of higher education Doctor of Philosophy and Doctor of Science candidates at higher military educational institutions (scientific and research institutions) of the Ministry of Defense of Ukraine" as of February,2017,n.o. 115, available at: http//www.zakon.rada.gov.ua.

11. Order of the Ministry of Defense of Ukraine "On Approval of the Instruction on the Procedure for Paying Moneylender Support to Armed Forces of Ukraine and Some Other Persons" as of June 11, 2008, n.o. 260, available at: http//www.zakon.rada.gov.ua.

\title{
РЕЗЮМЕ
}

Владимир Колесник, кандидат технических наук, старший научный сотрудник

Руслан Серветник, кандидат педагогических наук, старший научный сотрудник, Национальный университет обороны Украины имени Ивана Черняховского

\section{Проблемные вопросы механизма подготовки докторов философии вне адъюнктуры}

В статье отображены проблемные вопросы механизма получения высшего образования степени доктора философии вне адъюнктуры и возможные пути решения противоречий действующей нормативно-правовой базы относительно организации подготовки соискателей высшего образования в высших военных учебных заведениях (научных учреждениях).

Ключевые слова: высшее военное учебное заведение (научное учреждение); образовательно-научная программа; подготовки соискателей высшего образования степени доктора философии; нормативно-правовые документьл.

\section{SUMMARY}

\author{
Volodymyr Kolesnyk, \\ Candidate of Technical Science, \\ senior researcher, \\ Ruslan Servetnyk, \\ Candidate of Pedagogical Science, \\ senior researcher, \\ National Defense University of Ukraine \\ named after Ivan Cherniakhovskyi
}

\section{Topical issues on training mechanism of doctors of philosophy without post-graduate studying}


Introduction: During the last ten years, when the projects of reforming higher education in Ukraine were discussed, the main subject was the discussion of training improvement of candidates for higher education, mostly in the terms of joining the Bologna Process (the Bologna declaration, Berlin Communiqué), and attempts to integrate Ukrainian experience and its progress under new conditions. The reasons of these trends are the transition of the world community to the information society, as well as improvement of the information searching skills, the ability of self-education throughout life. As a result, these innovations became the defining sphere of a person's professional activities, of his/her actualization of all spheres of globalization of personal and social life in the conditions of the general civilization tendencies of the modern world. All these aspects demand from higher school to give young people opportunity to be integrated into different societies, promote their self-determination and be active and competitive.

Purpose: the purpose of the article is to develop methodological and practical recommendations for highly qualified military personnel training after post-graduate studying. Also, the emphasis on issues that may be solved by officials who organize training of scientific and scientific and pedagogical staff in higher military educational institutions (scientific and research institutions) was placed.

Methods: the method of analysis and synthesis and the method of expert evaluations are used.

Results: development of methodological recommendations for the definition of approaches to the training of higher education Doctor of Philosophy candidates without post-graduate training.

Originality: recommendations for the training of Doctor of Philosophy candidates without post-graduate studying program.

Conclusion: A considerable part of topical issues on training mechanism of doctors of philosophy without post-graduate studying is due to the requirements of the current normative legal acts. Measures for their solution will include adopting amendments, cancel or increasing the number of normative legal acts. Unfortunately, there are no highly qualified specialists with relevant knowledge in many scientific fields and in the structure of higher military educational institutions (scientific institutions) as well. Consequently, these issues require special attention of leaders, whose activities are related to the training of military personnel of the highest qualification.

The prospect of further scientific research is problem solving concerning the content of the individual curriculum of Doctor of Philosophy candidates in higher education who must ensure the formation of certain competencies to solve problems of different complexity in the future scientific and pedagogical (scientific) activities.

Key words: higher military educational institution (scientific institution); scientific and educational program for training of Doctor of Philosophy candidates in higher education; normative and legal documents. 